九州大学学術情報リポジトリ

Kyushu University Institutional Repository

\title{
A Progress on Nanocellulose as Binders for Loose Natural Fibres
}

Dharu Feby Smaradhana

Mechanical Engineering Department, Universitas Sebelas Maret

Ariawan, Dody

Mechanical Engineering Department, Universitas Sebelas Maret

Alnursyah, Rafli

Mechanical Engineering Department, Universitas Sebelas Maret

https://doi.org/10.5109/4068624

出版情報 : Evergreen. 7 (3)，pp.436-443，2020-09. 九州大学グリーンテクノロジー研究教育センター バージョン：

権利関係 : 


\title{
A Progress on Nanocellulose as Binders for Loose Natural Fibres
}

\author{
Dharu Feby Smaradhana ${ }^{1}$, Dody Ariawan ${ }^{1 *}$, Rafli Alnursyah ${ }^{1}$ \\ ${ }^{1}$ Mechanical Engineering Department, Universitas Sebelas Maret, Surakarta, \\ Indonesia
}

*Author to whom correspondence should be addressed:

E-mail: dodyariawan@staff.uns.ac.id

(Received January 22, 2020; Revised April 6, 2020; accepted September 3, 2020).

\begin{abstract}
Nanocellulose can be obtained by two ways: extracting from wood to be nanofibrillated cellulose (NFC) and synthesised from bacterial cellulose (BC). Typically, the use of nanocellulose is for coating of fibres or reinforcement of polymer to make nanocomposites. This nanocellulose had been developed to be binders for natural fibre non-wovens. This binder has function to hold the loose fibres together so that the mechanical properties are improved. This article reviews the use of nanocellulose as binder for improving the mechanical properties of nonwoven natural fibre preforms. The manufacturing process, the comparison to conventional polymer binders and the potential of this in the future are also discussed.
\end{abstract}

Keywords: nanocellulose, bacterial cellulose, nano-fibrillated cellulose, binder, non-woven, natural fibre

\section{Introduction}

The growing demand of greener products shows a significant increase due to the global problems such as global waste, high oil price and environmental of landfill sites ${ }^{1-3)}$. There are many efforts having been conducted in the area of polymers by adding natural fibres as the reinforcement to manufacture environmentally-friendly composite materials. Natural fibres are likely to be promising candidate for polymers as the replacement of glass fibres to produce greener composites due to its high specific stiffness and strength, wide availability and also renewability ${ }^{4-7}$. Though natural fibres have been used in some applications such as automotive ${ }^{8,9)}$, indoor element in housing ${ }^{10)}$ and interior panelling for train ${ }^{10)}$, this fibre still has drawbacks including incompability with hydrophobic polymers ${ }^{11-13)}$, low thermal stability ${ }^{14-18)}$ and inherent variability in dimensions and mechanical properties ${ }^{9,19-21)}$. A little effort can only be done for solving the latter problem. However there has been considerable research effort conducted to tackle with hydrophilic properties of natural fibres by surface modification to enhance fibre-matrix interface ${ }^{22-26)}$. Two of popular treatments (despite having been old treatments) for natural fibres is alkaline treatment ${ }^{27-31)}$ and silane treatment ${ }^{32-35)}$.

Another effort that can be done to enhance the properties of natural fibres is by forming non-woven preforms from natural fibres ${ }^{36-39}$. Processing natural fibres into non-wovens (or called preforms) can be done by braiding the yarns using needle-punching equipment
40-44). Non-wovens have good mechanical entanglement from cellulosic fibres and even can be utilised without matrix or resin. However, in order to get better bonding among the fibres, natural fibres non-wovens are commonly combined with the binders made of polymers (thermosets and thermoplastics) ${ }^{45,46}$. In other words, the use of binder actually has the same role as surface treatment for natural fibres which may increase not only the bonding between fibres and matrix during impregnation with polymer but also the entanglement among fibres. However, the use of conventional polymers evokes some problems including the incompability with natural fibres since polymers usually have hydrophobic properties.

In order to get green non-woven preforms, another alternative material can be used as binder. Nanocellulose which is recently investigated for coating natural fibres to enhance the fibre-matrix interface properties ${ }^{47-50)}$ has been developed to bind loose natural fibres to replace the role of conventional polymers as binders. There have been works focusing on this with utilising the hydrophilic behaviour of natural fibre to absorb the water in nanocellulose dispersion, so the nanocellulose is allowed to spread along the fibres ${ }^{51)}$ and will improve the bonding between the fibres in non-woven preforms which enhance the mechanical performance as well.

This review focuses on the recent progress in the development of nanocellulose as binders for upgrading the properties of natural fibre non-wovens. In section 2, the types of nanocellulose based on the sources and how it can 
be obtained are revealed. In section 3 , the effective methods to manufacture natural fibre non-wovens with the addition of nanocellulose binders are discussed. The comparison of nanocellulose and polymers as binders is also presented as well as the conclusion at last.

\section{Nanocellulose}

There are two ways of producing nanocellulose, bottom-up by biosynthesis of bacteria and top-down by disintegration of plant materials ${ }^{52,53)}$. In terms of biosynthesis of bacteria, nanocellulose resulted is called bacterial cellulose (BC) which can be produced by two methods ${ }^{53)}$. The first method is static culture resulting white BC pellicle at the air-liquid from the accumulation of a thick which has structure like leather ${ }^{53)}$. The second method is stirring culture which can form suspended fibre or irregular pellets based on synthesis ${ }^{54)}$. The latter method is known as the first method to produce BC introduced by Brown ${ }^{1)}$. According to Lee et al. ${ }^{52)}$, BC has lateral dimension of $25-86 \mathrm{~nm}$ and is highly crystalline nano-sized cellulose (see figure 1). It has degree of crystallinity of up to $90 \%$ without the impurities such as hemicellulose and lignin ${ }^{55-58)}$. Moreover, BC has young's modulus of up to 114 GPs for a single fibre ${ }^{59,60)}$. These properties have attracted many researcher to investigate its potential, especially in the area of tissue engineering ${ }^{55,61)}$, biomedical engineering ${ }^{62)}$ and advanced composites ${ }^{63)}$. $\mathrm{BC}$ can be used in various biomedical applications such as implants and scaffolds, drug delivery, and wound dressing materials ${ }^{64)}$.

Regarding nanocellulose produced using disintegration of plant materials, it is usually termed nano-fibrillated cellulose (NFC). There are techniques to extract NFC from plants. One of techniques is by using ultrasound to disintegrate larger bundles of natural fibres into small fibrils ${ }^{52,65-69)}$. Another technique is the use of highpressure homogeniser investigated by Turbak et al. ${ }^{70)}$ to decrease the size of wood fibres into the nanometre scale. Generally, NFC has similar diameter to BC at about 100 $\mathrm{nm}$. However, it has lower critical surface energy (42 $\mathrm{mN} / \mathrm{m})$ than BC $(57 \mathrm{mN} / \mathrm{m})$ due to its impurities which are

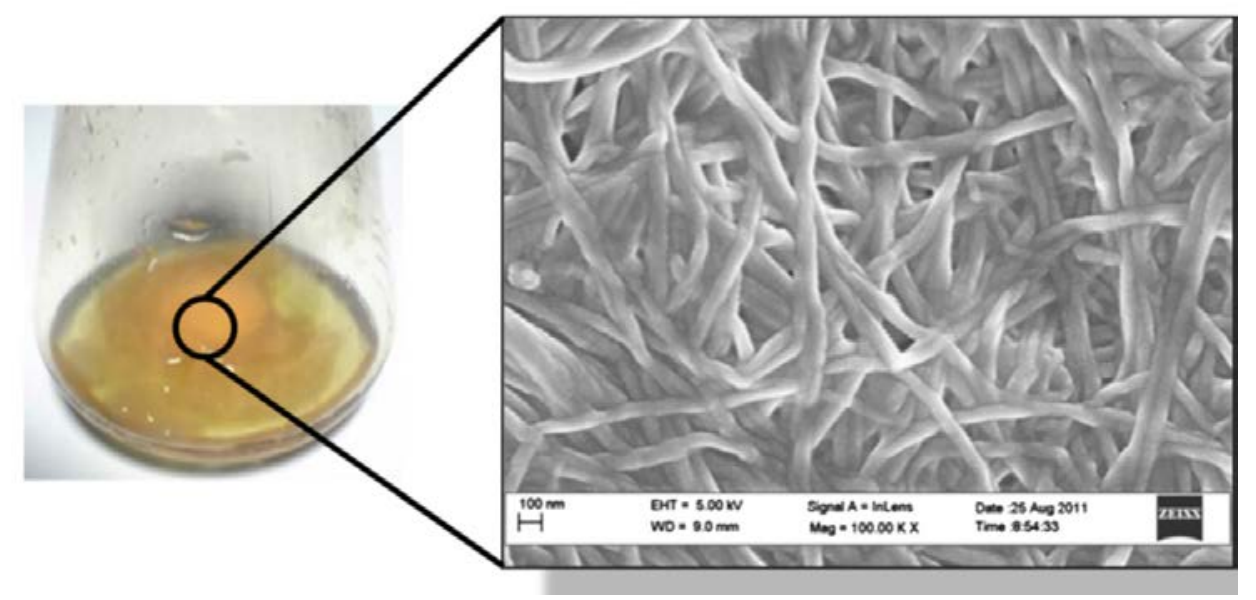

Fig. 1: Gel-like pellicle of BC and the appearance of pellicle under Scanning Electron Microscope (SEM) ${ }^{71)}$ with permission of ACS Publication.

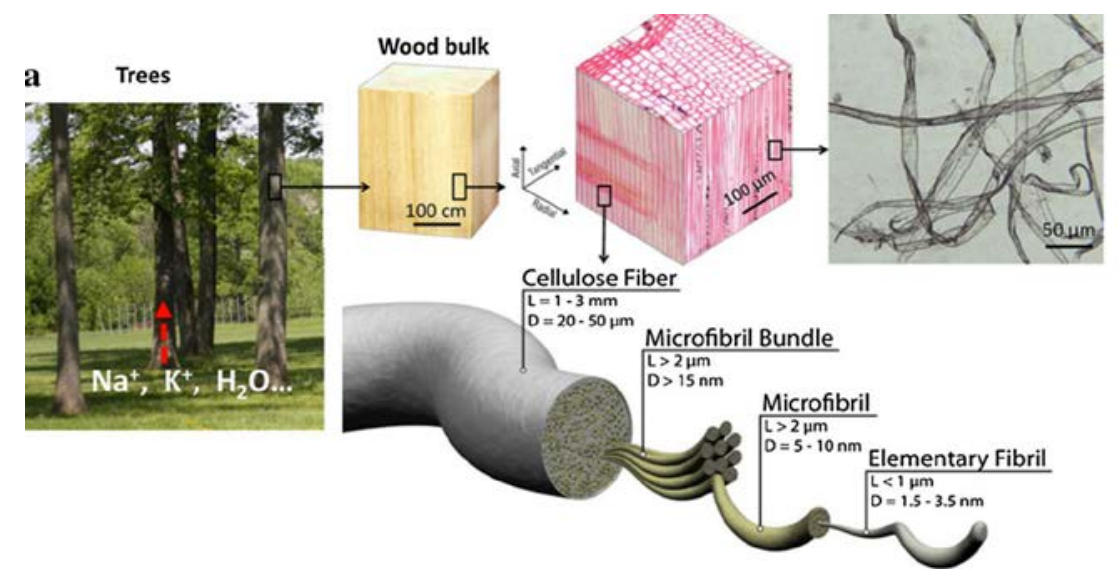

Fig. 2: Wood fibre structure ${ }^{2)}$, with permission of ACS. 


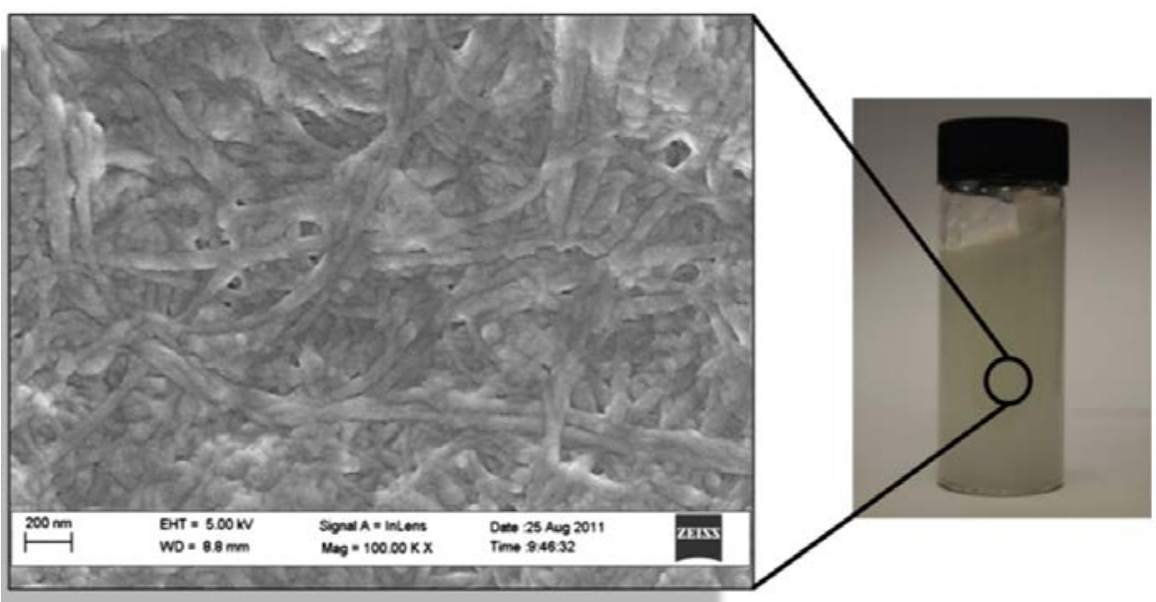

Fig. 3: NFC suspension ${ }^{71)}$ with permission of ACS.

affected by the presence of lignin and hemicellulose ${ }^{72,73)}$. Figure 2 shows the hierarchical structure of wood fibres followed by NFC suspension in water investigated using SEM (figure 3). NFC is also good as electrical insulation proven by Wang et al, ${ }^{74)}$. Due to good mechanical properties and electrical properties, the potential application of NFC is not only in the structural applications but also collapsible electronic devices ${ }^{74)}$.

\section{Natural Fibre Non-wovens with Nanocellulose Binders}

The use of BC as binders was developed by Lee et al. ${ }^{75,76)}$ using simple papermaking process to produce non-woven sisal fibre preforms. The manufacturing of fibre preforms was conducted by soaking sisal fibres in BC dispersion overnight, followed by dewatering, cold compression and hot compression at $120^{\circ} \mathrm{C}$ for $4 \mathrm{~h}$ to consolidate hornified nanocellulose network to form BCsisal fibre preforms. The results show that the addition of $10 \mathrm{wt}$ \% BC as binders increases tensile strength to $13.1 \pm$
$2.1 \mathrm{kNm}^{-1}$ and decreases porosity to $61 \%$ as shown in table 1. Tensile index presented in table 1 is the ratio of tensile strength $(\mathrm{N} / \mathrm{m})$ and grammage $\left(\mathrm{m}^{2} / \mathrm{g}\right)$ in which grammage is the areal density of non-wovens. Grammage usually uses to measure the density of paper. In addition, as shown in figure 4 that without the addition of BC binders, the natural fibres are loose and cannot be used to withstand load.

Fortea-Verdejo et al. ${ }^{77)}$ followed the process above to produce BC-flax fibre preforms and also used another nanocellulose type, nano-fibrillated cellulose (NFC) which is produced from wood via top-down approach ${ }^{52}$, and pulp to bind loose flax fibres. Two different filtration methods were also compared in this work: single filtration method (used by Lee et al. ${ }^{75,76)}$ as well) and a layer-bylayer filtration technique. The difference of single-step and a layer-by-layer filtration method is shown in figure 5 . The results show that nanocellulose (both BC and NFC) totally surpassed pulp as binder for flax nonwovens since pulp has lower surface area which leads to lower contact area between pulp and flax fibres.

Table 1. Properties of natural fibres using $10 \mathrm{wt} . \%$ of nanocellulose or other materials as binders

\begin{tabular}{|c|c|c|c|c|c|c|c|}
\hline Fibres & Binder & $\begin{array}{c}\text { Tensile strength } \\
\left(\mathrm{kNm}^{-1}\right)\end{array}$ & $\begin{array}{c}\text { Tensile strength } \\
(\mathrm{MPa})\end{array}$ & $\begin{array}{c}\text { Tensile index } \\
\left(\mathrm{N} \mathrm{m} \mathrm{g}^{-1}\right)\end{array}$ & $\begin{array}{c}\text { Flexural } \\
\text { strength (MPa) }\end{array}$ & $\begin{array}{c}\text { Flexural } \\
\text { modulus (GPa) }\end{array}$ & $\begin{array}{c}\text { Porosity } \\
(\%)\end{array}$ \\
\hline Sisal $^{75,76)}$ & BC & $13.1 \pm 2.1$ & - & - & - & - & $61 \pm 3$ \\
\hline Flax $^{77)}$ & BC & $6.5 \pm 1.5$ & $4.4 \pm 0.9$ & $7.5 \pm 1.9$ & $9.0 \pm 1.7$ & $0.8 \pm 0.3$ & $63.1 \pm 4.2$ \\
\hline Flax $^{77)}$ & NFC & $6.3 \pm 0.8$ & $5.0 \pm 0.7$ & $7.4 \pm 1.2$ & $7.0 \pm 1.8$ & $515 \pm 150$ & $57.7 \pm 2.9$ \\
\hline Flax $^{77) *}$ & BC & $17.6 \pm 2.5$ & $12.7 \pm 1.1$ & $19.6 \pm 2.3$ & $14.6 \pm 4.1$ & $1501 \pm 550$ & $57.1 \pm 2.2$ \\
\hline Flax $^{77) 22)}$ & PVA & 1.8 & - & 4.6 & - & - & $83 \pm 3$ \\
\hline Flax $^{78)}$ & PP & 5.4 & - & 14 & - & - & - \\
\hline
\end{tabular}

*manufactured by a layer-by-layer filtration method; PVA: Polyvinylalcohol 


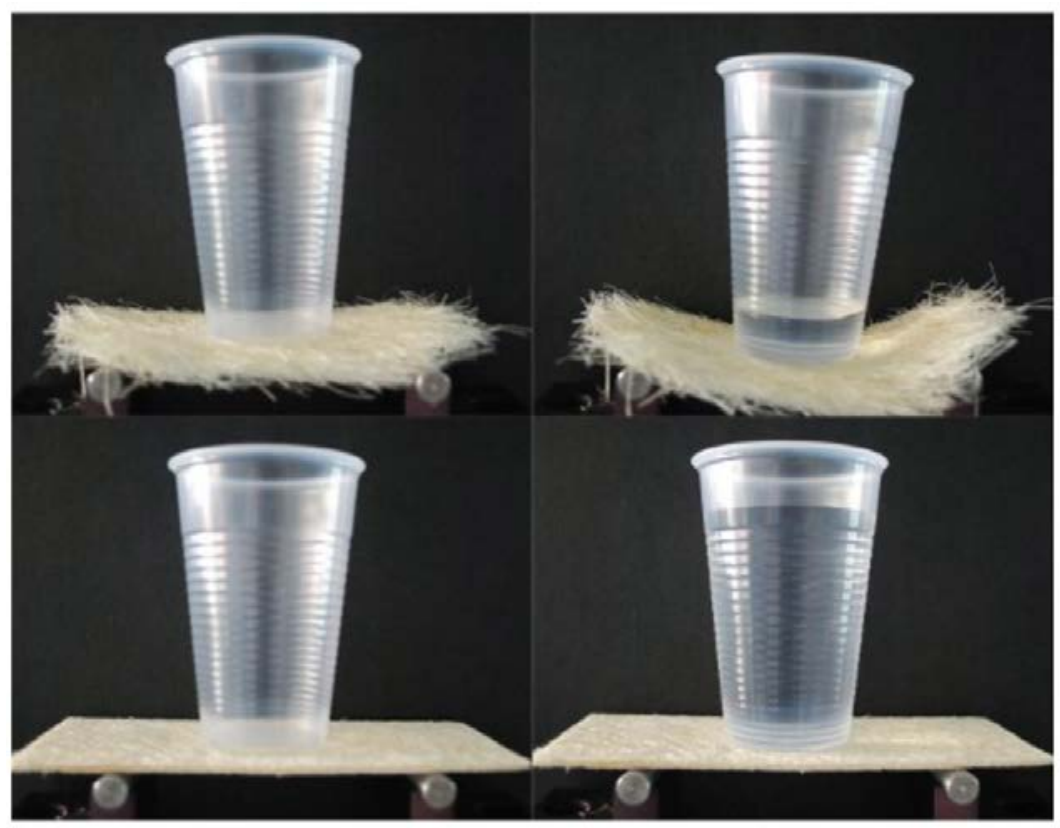

Fig. 4. Sisal fibres without the addition of BC (top) and sisal fibres with the addition of BC (bottom) with permission of JoVE ${ }^{76)}$.

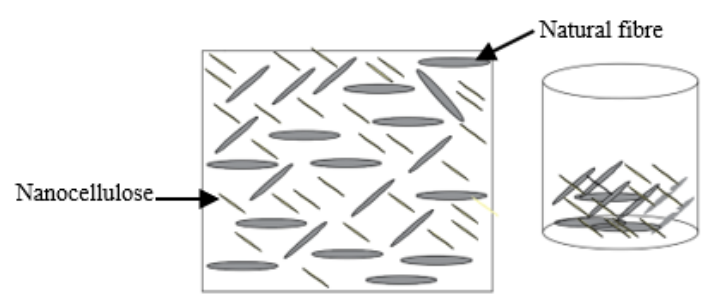

\section{Single-step filtration}
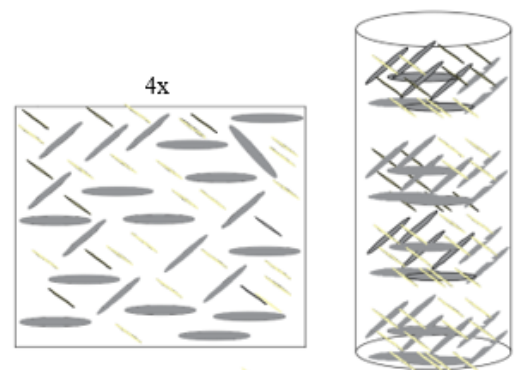

Layer-by-layer filtration

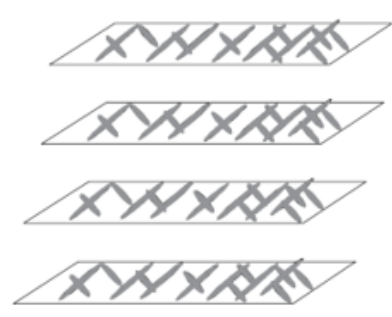

Fig. 5. Single-step and layer-by-layer filtration methods to produce natural fibre non-wovens with the addition of nanocellulose.

It can be seen in table 1 that BC-flax fibre preforms manufactured by a layer-by-layer filtration method had higher mechanical properties since the distribution of fibrous nanocellulose network throughout the non-woven preforms is more uniform ${ }^{77,79)}$. As shown in table 1 , BCsisal fibre preforms possesses higher mechanical properties than BC-flax fibre preforms having the same filtration method. However, once it is compared to BCflax fibre preform with a layer-by-layer filtration method, mechanical properties of BC-sisal preform were lower. This means that the mechanical properties of the nonwovens are not strongly dependent on the types of natural fibres but on the nanocellulose network because single-step filtration method has non-uniform nanocellulose network while layer-by-layer filtration method has more complex step and more thorough to ensure homogenous nanocellulose network which results better mechanical properties ${ }^{77)}$. Furthermore, the 
properties of all-natural nonwovens using nanocellulose as binders outperformed flax nonwovens using PVA binder which means that the addition of nanocellulose is more effective (table 1).

\section{Concluding Remarks}

The use of nanocellulose has been developed not only to coat natural fibres but also to be binders for the natural fibre nonwovens. This is agreed that the use of nanocellulose (from any source) can upgrade the properties of natural fibre preforms. A layer-by-layer filtration method is capable of enhancing the properties of the nonwovens to the next level. It is also remarked that the properties of natural fibres preform are highly influenced by the nanocellulose network structure, no matter the types of natural fibres used. The addition of nanocellulose as binder is also better than of conventional polymer (PVA) as binder. Using those method for binding natural fibre, nanocellulose does not only act as binder but also as nano-reinforcement which will enhance the mechanical performance of composites while impregnated into the resin. As suggestion, those methods can be used in other fibres (not only restricted to natural fibre) as long as it has hydrophilic nature which can absorb water in nanocellulose dispersion which makes nanocellulose spread along the fibres when fibres are soaked in nanocellulose dispersion. The layer of nanocellulose coating will be formed when the fibres are dried. The other potential fibres that can be used with the combination of nanocellulose binders are wood flour and recycled paper.

\section{References}

1) A.J. Brown, "XIX.- the chemical action of pure cultivations of bacterium aceti," J. Chem. Soc. Trans., 49 172-187 (1886).

2) H. Zhu, Z. Jia, Y. Chen, N. Weadock, J. Wan, O. Vaaland, X. Han, T. Li, and L. Hu, "Tin anode for sodium-ion batteries using natural wood fiber as a mechanical buffer and electrolyte reservoir," Nano Lett., 13 (7) 3093-3100 (2013).

3) H. Sosiati, Y.A. Shofie, and A.W. Nugroho, "Tensile properties of kenaf/e-glass reinforced hybrid polypropylene (pp) composites with different fiber loading,” Evergreen, 5 (2) 1-5 (2018). doi:10.5109/1936210.

4) N.G. Andre, D. Ariawan, and Z.A. Mohd Ishak, "Elastic anisotropy of kenaf fibre and micromechanical modeling of nonwoven kenaf fibre/epoxy composites,” J. Reinf. Plast. Compos., 35 (19) 1424-1433 (2016).

5) N.G. Andre, D. Ariawan, and Z.A. Mohd Ishak, "Mechanical properties and micromechanical analysis of nonwoven kenaf fibre/epoxy composites produced by resin transfer moulding," J. Compos. Mater., 51 (13) 1875-1885 (2017).
6) D. Ariawan, Z.A. Mohd Ishak, M.S. Salim, R. Mat Taib, M.Z. Ahmad Thirmizir, and H. Pauzi, "The effect of alkalization on the mechanical and water absorption properties of nonwoven kenaf fiber/unsaturated polyester composites produced by resin-transfer molding,” Polym. Compos., 37 (12) 3516-3526 (2016).

7) W.P. Raharjo, R. Soenoko, A. Purnowidodo, and A. Choiron, "Characterization of sodium-bicarbonatetreated zalacca fibers as composite reinforcements," Evergreen, 6 (1) 29-38 (2019). doi:10.5109/2321001.

8) M.S. Fogorasi, and I. Barbu, “The potential of natural fibres for automotive sector-review,” in: IOP Conf. Ser. Mater. Sci. Eng., IOP Publishing, 2017: p. 12044.

9) J. Sahari, and S.M. Sapuan, "Natural fibre reinforced biodegradable polymer composites,” Rev. Adv. Mater. Sci, 30 (2) 166-174 (2011).

10) K. Lau, P. Hung, M.-H. Zhu, and D. Hui, "Properties of natural fibre composites for structural engineering applications," Compos. Part B Eng., 136 222-233 (2018).

11) K. Charlet, F. Saulnier, D. Gautier, M. Pouzet, M. Dubois, and A. Béakou, "Fluorination as an effective way to reduce natural fibers hydrophilicity," in: Nat. Fibres Adv. Sci. Technol. Towar. Ind. Appl., Springer, 2016: pp. 211-229.

12) G.L. Devnani, and S. Sinha, "Effect of nanofillers on the properties of natural fiber reinforced polymer composites,” Mater. Today Proc., 18 647-654 (2019).

13) D.P. Ferreira, J. Cruz, and R. Fangueiro, "Surface modification of natural fibers in polymer composites," in: Green Compos. Automot. Appl., Elsevier, 2019: pp. 3-41.

14) R. Karnani, M. Krishnan, and R. Narayan, "Biofiberreinforced polypropylene composites,” Polym. Eng. Sci., 37 (2) 476-483 (1997). doi:10.1002/pen.11691.

15) W. Czaja, D. Romanovicz, and R. Malcolm Brown, "Structural investigations of microbial cellulose produced in stationary and agitated culture," Cellulose, 11 (3-4) 403-411 (2004).

16) Y. Xie, C.A.S. Hill, Z. Xiao, H. Militz, and C. Mai, "Silane coupling agents used for natural fiber/polymer composites: a review,” Compos. Part A Appl. Sci. Manuf., 41 (7) 806-819 (2010).

17) J. Sahari, and S.M. Sapuan, "NATURAL fibre reinforced biodegradable,” 30 166-174 (2011).

18) J. Rao, L. Bao, B. Wang, M. Fan, and L. Feo, "Plasma surface modification and bonding enhancement for bamboo composites," Compos. Part B Eng., 138 157-167 (2018).

19) K.-Y. Lee, "Nanocellulose and sustainability: production, properties, applications, and case studies," CRC Press, 2018.

20) J.L. Thomason, J. Carruthers, J. Kelly, and G. Johnson, "Fibre cross-section determination and variability in sisal and flax and its effects on fibre performance characterisation,” Compos. Sci. Technol., 
71 (7) 1008-1015 (2011).

21) A.K. Mohanty, M. Misra, and L.T. Drzal, "Natural fibers, biopolymers, and biocomposites," CRC press, 2005.

22) T. Boronat, and O. Fenollar, "The use of wet-laid techniques to obtain flax nonwovens with different thermoplastic binding fibers for technical insulation applications,"

(2013). doi:10.1177/0040517512454183.

23) R.M. Shahroze, M. Chandrasekar, K. Senthilkumar, T. Senthilmuthukumar, M.R. Ishak, and M.R.M. Asyraf, "A review on the various fibre treatment techniques used for the fibre surface modification of the sugar palm fibres," in: Semin. Enau Kebangs., 2019: pp. $48-52$.

24) J. Cruz, and R. Fangueiro, "Surface modification of natural fibers: a review,” (2016).

25) K.M. Praveen, S. Thomas, Y. Grohens, M. Mozetič, I. Junkar, G. Primc, and M. Gorjanc, "Investigations of plasma induced effects on the surface properties of lignocellulosic natural coir fibres," Appl. Surf. Sci., 368 146-156 (2016).

26) Y. Liu, X. Lv, J. Bao, J. Xie, X. Tang, J. Che, Y. Ma, and J. Tong, "Characterization of silane treated and untreated natural cellulosic fibre from corn stalk waste as potential reinforcement in polymer composites," Carbohydr. Polym., 218 179-187 (2019).

27) J. Gassan, "A study of fibre and interface parameters affecting the fatigue behaviour of natural fibre composites," Compos. Part A Appl. Sci. Manuf., 33 (3) 369-374 (2002).

28) M. Rokbi, H. Osmani, A. Imad, and N. Benseddiq, "Effect of chemical treatment on flexure properties of natural fiber-reinforced polyester composite," Procedia Eng., 10 (0) 2092-2097 (2011).

29) D. Bachtiar, S.M. Sapuan, and M.M. Hamdan, "The influence of alkaline surface fibre treatment on the impact properties of sugar palm fibre-reinforced epoxy composites,” Polym. Plast. Technol. Eng., 48 (4) 379-383 (2009).

30) D. Bachtiar, S.M. Sapuan, and M.M. Hamdan, "The effect of alkaline treatment on tensile properties of sugar palm fibre reinforced epoxy composites," Mater. Des., 29 (7) 1285-1290 (2008).

31) D. Bachtiar, S.M. Sapuan, and M.M. Hamdan, "Flexural properties of alkaline treated sugar palm fibre reinforced epoxy composites," Int. J. Automot. Mech. Eng., 1 (1) 79-90 (2010).

32) M. Abdelmouleh, S. Boufi, M.N. Belgacem, and A. Dufresne, "Short natural-fibre reinforced polyethylene and natural rubber composites: effect of silane coupling agents and fibres loading," Compos. Sci. Technol., 67 (7-8) 1627-1639 (2007).

33) P.J. Herrera-Franco, and A. Valadez-Gonzalez, "Mechanical properties of continuous natural fibrereinforced polymer composites," Compos. Part A
Appl. Sci. Manuf., 35 (3) 339-345 (2004).

34) J. Gassan, V.S. Gutowski, and A.K. Bledzki, "About the surface characteristics of natural fibres," Macromol. Mater. Eng., 283 (1) 132-139 (2000).

35) E.T.N. Bisanda, and M.P. Ansell, "The effect of silane treatment on the mechanical and physical properties of sisal-epoxy composites," Compos. Sci. Technol., 41 (2) 165-178 (1991).

36) V.C. Chenoweth, and R.C. Goodsell, "Non-woven fibrous product containing natural fibers," (1993).

37) K. Balan, "Studies on engineering behaviour and uses of geotextiles with natural fibres.," (1995).

38) J. George, and J.I. Verpoest I, "Mechanical properties of flax fibre reinforced epoxy composites," Die Angew. Makromol. Chemie, 272 (1) 41-45 (1999).

39) H.N. Dhakal, Z.Y. Zhang, M.O.W. Richardson, and O.A.Z. Errajhi, "The low velocity impact response of non-woven hemp fibre reinforced unsaturated polyester composites," Compos. Struct., 81 (4) 559567 (2007).

40) D.T. Bergado, S. Youwai, C.N. Hai, and P. Voottipruex, "Interaction of nonwoven needlepunched geotextiles under axisymmetric loading conditions," Geotext. Geomembranes, 19 (5) 299328 (2001).

41) F. Shahani, P. Soltani, and M. Zarrebini, "The analysis of acoustic characteristics and sound absorption coefficient of needle punched nonwoven fabrics," J. Eng. Fiber. Fabr., 9 (2) 155892501400900220 (2014).

42) B. de S. Bueno, M.A. Costanzi, and J.G. Zornberg, "Conventional and accelerated creep tests on nonwoven needle-punched geotextiles," Geosynth. Int., 12 (6) 276-287 (2005).

43) K. Mieck, R. Lützkendorf, and T. Reussmann, "Needle-Punched hybrid nonwovens of flax and ppfibers - textile semiproducts for manufacturing of fiber composites,” Polym. Compos., 17 (6) 873-878 (1996).

44) R.D. Anandjiwala, and L. Boguslavsky, "Development of needle-punched nonwoven fabrics from flax fibers for air filtration applications," Text. Res. J., 78 (7) 614-624 (2008).

45) G.N. Ramaswamy, T. Sellers, and W. Tao, "Kenaf nonwovens as substrates for laminations," Ind. Crops Prod., 17 (1) 1-8 (2003).

46) W. Tao, T.A. Calamari, and L. Crook, "Carding kenaf for nonwovens,” Text. Res. J., 68 (6) 402-406 (1998).

47) K.Y. Lee, P. Bharadia, and A. Bismarck, "Nanocellulose surface coated support material," (2015).

48) M. Pommet, J. Juntaro, J.Y.Y. Heng, A. Mantalaris, A.F. Lee, K. Wilson, G. Kalinka, M.S.P. Shaffer, and A. Bismarck, "Surface modification of natural fibers using bacteria: depositing bacterial cellulose onto natural fibers to create hierarchical fiber reinforced nanocomposites," Biomacromolecules, 9 (6) 1643- 
1651 (2008).

49) A. Jabbar, J. Militký, J. Wiener, B.M. Kale, U. Ali, and S. Rwawiire, "Nanocellulose coated woven jute/green epoxy composites: characterization of mechanical and dynamic mechanical behavior," Compos. Struct., 161 340-349 (2017).

50) A. Jabbar, J. Militký, A. Ali, and M.U. Javed, "Investigation of Mechanical and Thermomechanical Properties of Nanocellulose Coated Jute/Green Epoxy Composites,” in: Adv. Nat. Fibre Compos., Springer, 2018: pp. 175-194.

51) K. Lee, P. Bharadia, J.J. Blaker, and A. Bismarck, "Composites: part a short sisal fibre reinforced bacterial cellulose polylactide nanocomposites using hairy sisal fibres as reinforcement," Compos. PART A, 43 (11) 2065-2074 (2012). doi:10.1016/j.compositesa.2012.06.013.

52) K. Lee, Y. Aitomäki, L.A. Berglund, K. Oksman, and A. Bismarck, "On the use of nanocellulose as reinforcement in polymer matrix composites," Compos. Sci. Technol., 105 15-27 (2014). doi:10.1016/j.compscitech.2014.08.032.

53) A.F. Jozala, L.C. De Lencastre-novaes, A.M. Lopes, V.D.C. Santos-ebinuma, P.G. Mazzola, and A. Pessoa-jr, "Bacterial nanocellulose production and application: a 10-year overview,” (2016). doi:10.1007/s00253-015-7243-4.

54) I. Reiniati, A.N. Hrymak, and A. Margaritis, "Recent developments in the production and applications of bacterial cellulose fibers and nanocrystals," Crit. Rev. Biotechnol., $37 \quad$ (4) 510-524 (2017). doi:10.1080/07388551.2016.1189871.

55) D. Klemm, B. Heublein, H.-P. Fink, and A. Bohn, "Cellulose: fascinating biopolymer and sustainable raw material,” Angew. Chemie Int. Ed., 44 (22) 33583393 (2005). doi:10.1002/anie.200460587.

56) H.-J. Son, H.-G. Kim, K.-K. Kim, H.-S. Kim, Y.-G. Kim, and S.-J. Lee, "Increased production of bacterial cellulose by acetobacter sp. v6 in synthetic media under shaking culture conditions," Bioresour. Technol., 86 (3) 215-219 (2003).

57) D. Klemm, F. Kramer, S. Moritz, T. Lindström, M. Ankerfors, D. Gray, and A. Dorris, "Nanocelluloses: a new family of nature-based materials," Angew. Chemie Int. Ed., 50 (24) 5438-5466 (2011).

58) D. Klemm, D. Schumann, F. Kramer, N. Heßler, M. Hornung, H.-P. Schmauder, and S. Marsch, "Nanocelluloses as innovative polymers in research and application,” in: Polysaccharides Ii, Springer, 2006: pp. 49-96.

59) Y.-C. Hsieh, H. Yano, M. Nogi, and S.J. Eichhorn, "An estimation of the young's modulus of bacterial cellulose filaments," Cellulose, 15 (4) 507-513 (2008).

60) S. Gea, C.T. Reynolds, N. Roohpour, B. Wirjosentono, N. Soykeabkaew, E. Bilotti, and T. Peijs, "Investigation into the structural, morphological, mechanical and thermal behaviour of bacterial cellulose after a two-step purification process," Bioresour. Technol., 102 (19) 9105-9110 (2011).

61) D. Klemm, D. Schumann, F. Kramer, N. Heßler, D. Koth, and B. Sultanova, "Nanocellulose materials different cellulose, different functionality," Macromol. Symp., $280 \quad$ (1) 60-71 (2009). doi:10.1002/masy.200950608.

62) J.J. Blaker, K.-Y. Lee, and A. Bismarck, "Hierarchical composites made entirely from renewable resources," J. Biobased Mater. Bioenergy, 5 (1) 1-16 (2011).

63) K.-Y. Lee, G. Buldum, A. Mantalaris, and A. Bismarck, "More than meets the eye in bacterial cellulose: biosynthesis, bioprocessing, and applications in advanced fiber composites," Macromol. Biosci., 14 (1) 10-32 (2014). doi:10.1002/mabi.201300298.

64) H.G. de Oliveira Barud, R.R. da Silva, H. da Silva Barud, A. Tercjak, J. Gutierrez, W.R. Lustri, O.B. de Oliveira Junior, and S.J.L. Ribeiro, “A multipurpose natural and renewable polymer in medical applications: bacterial cellulose,” Carbohydr. Polym., 153 406-420 (2016).

65) W. Li, J. Yue, and S. Liu, "Preparation of nanocrystalline cellulose via ultrasound and its reinforcement capability for poly (vinyl alcohol) composites," Ultrason. Sonochem., 19 (3) 479-485 (2012).

66) S. Putthanarat, N. Stribeck, S.A. Fossey, R.K. Eby, and W.W. Adams, "Investigation of the nanofibrils of silk fibers,” Polymer (Guildf)., 41 (21) 7735-7747 (2000).

67) A. Olszewska, P. Eronen, L.-S. Johansson, J.-M. Malho, M. Ankerfors, T. Lindström, J. Ruokolainen, J. Laine, and M. Österberg, "The behaviour of cationic nanofibrillar cellulose in aqueous media," Cellulose, 18 (5) 1213 (2011).

68) D.V. Pinjari, and A.B. Pandit, "Cavitation milling of natural cellulose to nanofibrils," Ultrason. Sonochem., 17 (5) 845-852 (2010).

69) S.P. Mishra, A.-S. Manent, B. Chabot, and C. Daneault, "Production of nanocellulose from native cellulose-various options utilizing ultrasound," BioResources, 7 (1) 422-436 (2012).

70) A.F. Turbak, F.W. Snyder, and K.R. Sandberg, "Microfibrillated cellulose, a new cellulose product: properties, uses, and commercial potential,” in: J. Appl. Polym. Sci. Appl. Polym. Symp.;(United States), ITT Rayonier Inc., Shelton, WA, 1983.

71) K.-Y. Lee, T. Tammelin, K. Schulfter, H. Kiiskinen, J. Samela, and A. Bismarck, "High performance cellulose nanocomposites: comparing the reinforcing ability of bacterial cellulose and nanofibrillated cellulose,” ACS Appl. Mater. Interfaces, 4 (8) 40784086 (2012).

72) A. Jebali, S. Hekmatimoghaddam, A. Behzadi, I. Rezapor, B.H. Mohammadi, T. Jasemizad, S.A. 
Yasini, M. Javadzadeh, A. Amiri, and M. Soltani, "Antimicrobial activity of nanocellulose conjugated with allicin and lysozyme,” Cellulose, 20 (6) 28972907 (2013).

73) Q. Li, S. McGinnis, C. Sydnor, A. Wong, and S. Renneckar, "Nanocellulose life cycle assessment," ACS Sustain. Chem. Eng., 1 (8) 919-928 (2013).

74) X. Wang, and P. Wu, "Fluorinated carbon nanotube/nanofibrillated cellulose composite film with enhanced toughness, superior thermal conductivity, and electrical insulation," ACS Appl. Mater. Interfaces, 10 (40) 34311-34321 (2018).

75) K. Lee, K.K.C. Ho, K. Schlufter, and A. Bismarck, “Author' s personal copy hierarchical composites reinforced with robust short sisal fibre preforms utilising bacterial cellulose as binder," (n.d.).

76) K. Lee, S.R. Shamsuddin, M. Fortea-verdejo, and A. Bismarck, "Manufacturing of robust natural fiber preforms utilizing bacterial cellulose as binder 4 . composite manufacturing using vacuum assisted resin infusion ( vari ),” (May) 1-8 (2014). doi:10.3791/51432.

77) M. Fortea-verdejo, K. Lee, T. Zimmermann, and A. Bismarck, "Composites: part a upgrading flax nonwovens : nanocellulose as binder to produce rigid and robust flax fibre preforms," Compos. Part A, 83 63-71

(2016). doi:10.1016/j.compositesa.2015.11.021.

78) E. Fages, M.A. Cano, S. Girones, T. Boronat, O. Fenollar, and R. Balart, "The use of wet-laid techniques to obtain flax nonwovens with different thermoplastic binding fibers for technical insulation applications,” Text. Res. J., 83 (4) 426-437 (2013).

79) M. Fortea-Verdejo, and A. Bismarck, "Upgrading the Properties of Woven and Non-Woven (Ligno) Cellulosic Fibre Preforms with Nanocellulose,” in: Nanocellulose Sustain., CRC Press, 2018: pp. 197216. 